\title{
BEYOND SAY'S LAW: THE SIGNIFICANCE OF J.-B. SAY'S MONETARY VIEWS
}

\author{
BY \\ ALAIN BÉRAUD AND GUY NUMA
}

\begin{abstract}
Jean-Baptiste Say's notion of débouchés has not been correctly understood, due to the lack of proper context within the framework of his broader political economy. We revisit Say's writings on this topic, retrace the concept's evolution, and lay out a framework that better illustrates the essence of Say's thinking. We argue that Say's theories on money and economic crises are much richer and more sophisticated than the traditional interpretation of Say's Law would suggest. Say himself acknowledged that his monetary theory contradicted his initial articulations of the law, a point often missed by contemporary observers. This essay paints a more complete picture of Say's work, showing how monetary changes could, under his framework, affect real variables. In so doing, it cuts against the many simplistic interpretations that pervade the existing literature on the subject.
\end{abstract}

Despite the principles that teach us that money plays only the role of a simple intermediary, and that products can ultimately be purchased only with products, more abundant money fosters all sales and the reproduction of new values.

—Say, Cours complet d'économie politique pratique

\section{INTRODUCTION}

Previous studies on Jean-Baptiste Say published in the English language have focused overwhelmingly on the so-called Say's Law. ${ }^{1}$ In doing so, analysts have overlooked

\footnotetext{
Alain Béraud, THEMA, University of Cergy-Pontoise, France; Guy Numa, Economics Department and Honors College, University of Massachusetts Boston, USA. Email: guy.numa@umb.edu. We are grateful to Perry Mehrling, Gonçalo Fonseca, Ian Kumekawa, Nathaniel Donahue, two anonymous referees, and the editor of $J H E T$ for their pertinent comments. Guy Numa gratefully acknowledges the assistance of the Joseph P. Healey Research Grant program of the University of Massachusetts Boston. Some portions of the present essay borrow from Béraud (2014).

${ }^{1}$ See, for instance, Baumol (1977, 1999), Becker and Baumol (1952), Blaug (1997, pp. 143-160), Clower and Leijonhufvud ([1973] 1981), Hutt (1963, pp. 387-406; 1974), Kates (1998, 2003), Lange ([1942] 1970), Niehans (1990, pp. 105-117), Patinkin (1965, pp. 645-650), and Sowell (1972, 1987), among others. For additional references, see Wood and Kates (2000).
} 
Say's lengthy writings on money. ${ }^{2}$ The debates that result from this focus on Say's Law consequently suffer from two shortcomings. First, they tend to entertain the erroneous idea that, for Say, money played only the role of simple intermediary. Second, they fail to explore the contradiction between Say's Law and Say's actual monetary views. ${ }^{3}$

The purpose of this essay is to examine the connection between Say's loi des débouchés (hereafter "law of outlets") 4 and Say's monetary theory. Say believed that the value of money was determined by supply and demand, which implied that individuals could alter their holdings of money. Say never meant that supply created its own demand, but simply meant that selling goods increased one's holdings of money, thus potentially, but not necessarily, allowing the purchase of other goods with the proceeds of the sale. Say conceded that monetary changes not only affected prices, but also affected expenditure, output, and the distribution of wealth. For Say, money was not merely a medium of exchange.

Several points should be clarified before going further into the text. First, this essay is not a survey of the primary and secondary literature on "the study of the causes that open greater or lesser outlets to our products" (Say [1828-29] 2010, p. 349). Our focus is on Say's writings. We do not address the issue of whether Say was the only or the first originator of what came to be known as "Say's Law." Paul Lambert (1952), Andrew Skinner (1967), and William Thweatt (1979) show that Say's analyses carried on an earlier tradition marked by the contributions of Francis Hutcheson ([1725-26] 1750, p. 63), A. R. Jacques Turgot ([1766] 1914, p. 588), and Adam Smith ([1776] 1976, pp. 337-338). In the early nineteenth century, many authors-James Mill (1808, p. 81), David Ricardo ([1817] 1951, p. 290), and John Stuart Mill (1844, p. 48), for instance-developed their own reasoning on outlets, which could not be considered as strictly similar to Say's.

Second, Say published three major opuses: Catéchisme d'économie politique, Cours complet d'économie politique pratique (hereafter Cours), and Traité d'économie politique (hereafter Traité). Each work contains several chapters on money and banking, particularly the last two. Traité presents some difficulties particularly for modern readers: the book was published in six editions released in $1803,1814,1817$, 1819, 1826, and 1841; Say made substantial revisions that traced the evolution of his thinking. Most English-speaking analysts of Say rely on the fourth edition, translated into English in 1821 by Charles Robert Prinsep. This edition remains the only one translated into English to this date. New editions of this text were printed in the US in 1821, 1824, 1827, 1830, 1832, 1834, and 1836, with several later reprints (Potier 2006, p. $1 x x x)$. However, they were translations of the fourth edition. ${ }^{5}$ Yet, following the

\footnotetext{
${ }^{2}$ Jacoud (2013, pp. 1-22) is one exception. Another is Tiran (2003), a study published in the French language.

${ }^{3}$ Eltis (2005) is one exception, but the author's analysis of money in Say's writings is limited.

${ }^{4}$ Say's loi des débouchés is poorly rendered into English as "law of markets" in the literature. "Outlets," "market opportunities," "market openings," or "vents" are English equivalents for débouchés. Depending on the context, Say's formulation can be translated by any of these terms. We opted for "outlets," which was first used by Lalor ([1881] 1884, 3, pp. 38-40) and later by Baumol (1977, p. 147). Translations of Say's writings are ours unless otherwise noted.

${ }^{5}$ The American editor Clement Cornell Biddle simply restored the Discours préliminaire omitted by Prinsep, removed Prinsep's notes since he found them too Ricardian, and substituted his own notes (Potier 2006, p. 1xx).
} 
publication of Thomas Tooke's Considerations on the State of the Currency in 1826, Say significantly revised the chapters on money in the fifth edition of Traité. Indeed, the 1825 crisis in England exerted a profound impact on Say's thinking. From that point on, he emphasized the effects of monetary changes on the state of the economy, which led him to develop a monetary theory of crises (Hollander 2005, pp. 209-214).

Last, it should be noted that Say was very well acquainted with monetary and banking issues. He was trained in the family's business (his father was a banker and currency trader), and at one point he worked for Étienne Clavière's insurance company. ${ }^{6}$ His expertise with monetary matters led him to author a report for the Tribunat concerning the bill for the recoinage of monies in March 1803. ${ }^{7}$

Say's formulations of the law of outlets in the first two editions of Traite did not constitute a monolithic dictum (i.e., supply creates its own demand), but rather formed a multifaceted set of ideas about the relationships between the production and demand for commodities. Say constantly revised his positions, as evidenced by the multiple editions of Traité. Say's thinking was especially dynamic on the issue of outlets. In the first edition, Say made crucial statements on the topic. In the second, his thinking changed substantially (Baumol 1977, pp. 157-159). The changing economic context that arose after Napoleon's downfall provoked new questions about Say's economic theory, and his ideas were more scrutinized by his contemporaries. Growing criticisms compelled him to modify his views on several points, particularly on the demand for money. Section II retraces the evolution of Say's views on outlets. We revisit some key passages and point out some misinterpretations in the literature. By means of rational reconstructions, we lay out a framework that better illustrates, in our view, the essence of Say's thinking.

Previous studies have analyzed Say's ideas on outlets without taking into account other aspects of his writings. In particular, two major related topics should be considered: his monetary theory and his theory of crises. Oscar Lange ([1942] 1970, pp. 149, 164) argues that if the total value of the demand for commodities is identically equal to the total value of supply, it is possible to determine the equilibrium values of the relative prices of commodities, but not the monetary prices. This scenario precludes any substitution of money for commodities or vice versa. ${ }^{8}$ In other words, according to Lange, Say's Law depicted a barter economy in which money was merely a medium of exchange. In reality, as demonstrated in section III, Say moved away from such thinking, as it was inconsistent with his monetary theory. Say defended the idea that supply and demand determined the value of money, which led him to adopt quantity

\footnotetext{
${ }^{6}$ On the role played by Clavière in Say's life, see Whatmore (2000, pp. 10-12, 77-82). For additional biographical details, see Blanc and Tiran (2003) and Schoorl (2013).

${ }^{7}$ Tribunat was a French legislative body from 1800 to 1807.

${ }^{8}$ Yet, Say admitted the possibility of such substitution. In the first edition of Traité, Say wrote: "[T]he glut only takes place when too many means of production are used for producing one type of production and not enough for another. Indeed, what is a lack of sales? This is when it is difficult to obtain a merchandise (good or money) in exchange for the merchandise that one supplies" ([1803] 2006, p. 690). Say explicitly stated that the seller could receive either money or another commodity. One can argue that this passage conveys an idea that Clower and Leijonhufvud (1981 [1973], p. 81) called "Say's Principle" - the net value of an individual's planned trades is identically zero-as opposed to Oscar Lange's formulation of Say's Law, which states that "the total demand for commodities (exclusive of money) is identically equal to their total supply (Lange [1942] 1970, p. 153).
} 
theoretic positions. Nonetheless, in his mind, money was not neutral. Say conceded that monetary expansion could promote increased expenditure and output.

In the preface of the French edition of the General Theory, John Maynard Keynes ([1939] 1973, p. xxxv) alleged that a theory that rests on Say's Law "is clearly incompetent to tackle the problems of unemployment and of the trade cycle." However, even though Say did not develop a formal trade cycle theory, he did analyze economic crises. Thus, Say acknowledged that monetary changes could originate crises throughout the banking sector. This topic is discussed in section IV. Section V concludes the study.

\section{SAY ON OUTLETS}

In none of the editions of Traité did Say assume that money holdings remained unchanged. Agents could in fact alter their holdings of money. In the first edition, Say observed that changes in the holdings of money were usually minimal. He then explained in the second edition that such changes could result from an increasing quantity of monetary substitutes. Changes in the holdings of money, Say later argued, could also originate from coordination failures between suppliers and demanders of factor services.

\section{3: Money, Trade, and Savings}

In the first edition of Traité, chapter XXII of book I, Say opposed the views of economists such as James Steuart (1767) and François Véron de Forbonnais (1754), who hypothesized that international trade played a pivotal role in economic development by opening up new markets, and by increasing the quantity of coins and bullions in circulation within a country. First, Say argued that the abundance of money did not affect trade. In light of that fact, he then concluded that it was pointless to favor a trade surplus in order to enhance the stock of gold and silver. The first idea was articulated in a way that seemed to convey what Gary Becker and William Baumol (1952, p. 357) call Say's "identity":9

Money is used [for trading] almost like posters and handbills that, in a large city, facilitate the intercourse of people who may want to do business together. At the end of the year, each producer used a very large amount of money, but except for a few insignificant balances, generally there is no more money in his hands at the end of the year than he had at the beginning. What matters is what he purchases with this money, in other words the products sold by others that he traded for his.... In the end, [when] the exchanges have been completed, it turns out that one has paid for products with products. (Say [1803] 2006, pp. 244-246)

However, Say did not intimate that the quantity of money held by each producer necessarily remained unchanged. Admittedly, changes were usually minimal, but this was just an empirical fact, not a logical rule. Even if Say's formulation appeared to describe the so-called Say's identity, this interpretation is unsatisfactory and should be rejected. Say essentially asserted that, except for downturns, the extent of hoarding

\footnotetext{
${ }^{9}$ Also reiterated by Eltis (2005, p. 667$)$, who asserts that what is implied by the passage above, among others, "is clearly the identity version of the law."
} 
and dishoarding would in no way affect the extent of outlets. Moreover, the fact that each producer held "no more money in his hands at the end of the year than he had at the beginning" did not imply that planned or desired holdings of money were equal to actual holdings. Indeed, in order to increase the money holdings, an agent must reduce his demand and/or augment his supply. If all agents aimed to increase their holdings, an excess supply of commodities would appear and lead to falling prices or lead to greater purchasing power of money, which was equivalent. Assuming that the quantity of money in the economy remained constant, each agent would be left with unchanged nominal holdings of money, but increased real holdings.

Say also touched upon the issue of outlets in chapter V of book IV of Traité and in chapter III of book V. Say criticized Germain Garnier's view that overproduction would impede the circulation of goods if an equivalent level of consumption did not absorb the national product (Garnier 1802, 5, p. 241), ${ }^{10}$ and instead argued that production was not bounded by consumption, but by the means of production. Say reiterated that "the total demand for products is always equal to the sum of products," and therefore general overproduction could not occur (Say [1803] 2006, p. 688). If demand could not match supply, too much of the means of production was used to produce a given commodity, and therefore too little must necessarily have been employed in the production of another commodity. Furthermore, "as the scope of production depended upon the scope of means of production, the demand for means of production covers in the same proportion [the quantity of] means of production.... A nation is always able to purchase all what it produces" (Say [1803] 2006, p. 692). All the elements that, according to Keynes ([1939] 1973, p. xxxv), characterize Say's Law seem to be valid at first sight: the means of production are entirely used, and supply created its own demand. However, two questions remain unanswered. First, if the national income was equal to the national product, a nation was always able to purchase its entire production, but could we take as a given the fact that it would? And, second, what was the effect of a partial imbalance-excess supply of a given commodity alongside excess demand for another-on the global equilibrium?

In chapter III of book V, Say criticized Pierre-Paul Mercier de la Rivière's view that saving ${ }^{11}$ was inimical to prosperity (Mercier de la Rivière 1767, 2, p. 138), pointing out that one individual's savings would be made available to others, who could put the savings to productive use, thereby augmenting productive capacity (Say [1803] 2006, pp. 892-894). ${ }^{12}$

The overall point was that in the first edition of Traité, Say noticed that money holdings remained essentially unchanged-without making a categorical claim-and that all saved income would be made available for productive use by entrepreneurs. Savings allowed production to grow, increased income, and therefore increased the extent of outlets.

\footnotetext{
${ }^{10}$ Garnier's analysis was similar to the thesis championed much later by the stagnationist Keynesians. His reasoning implied that because of a low rate of profit, investment could not absorb abundant savings.

${ }^{11}$ Say ([1826] 2006, p. 1109) defined "savings" as "the portions of profits that are not used for unproductive consumption, that are set aside in order to be added to capital. It is the accumulation of savings that creates capital."

${ }^{12}$ Say also used those arguments to criticize Dupont de Nemours (1770, p. 124), who argued that saving was sterile, destructive, and detrimental to the economy.
} 


\section{4: Monetary Expedients Substitute for the Lack of Cash}

Say heavily revised the second edition of Traité. He changed the plan of the text; this change of form was a reflection of the profound evolution of his thinking (Steiner 2006). This was particularly the case on the issue of outlets. Say now claimed that money holdings could change, because market forces would respond to any increased demand for money by making available substitutes for specie-bills of exchange, banknotes, or other credit instruments: "[A]ny shortage of cash ... can easily be overcome.... The intermediary merchandise that facilitates exchanges (money) is in those cases quite easily replaced by [other] means used by the merchants; and soon money begins to flow, because any sort of merchandise is directed toward places where one needs it" (Say [1814] 2006, p. 248). Additionally, in the monetary system implicit to Say's argument, the quantity of metallic money was not fixed. A shortage of specie would also lead to imports of gold or silver, so that the quantity of money (including all types of circulating medium) was endogenously determined (Say [1814] 2006, p. 292).

Say then addressed the problem of excess supplies of particular commodities. In the first edition, Say argued that an excess supply of one commodity would necessarily be matched by an offsetting excess demand for another commodity, so that increasing output of the commodity for which there was an excess demand would eliminate the excess supply of the other commodity (Say [1803] 2006, p. 246). In the second edition, Say focused on the relation between incomes and demand, pointing out that an excess supply of some products reflected insufficient output of other products, so that if more of the other products had been produced, the incomes thereby generated would have implied an increased demand for the products now unsold (Say [1814] 2006, p. 250). The problem was caused by a misallocation of resources: "[I]t is because the production of the missing products declined, that the overproduced products do not sell, and their value dropped. In more common terms, many people bought less because they earned less; and they earned less because they faced difficulty using their means of production, or because these means of production were lacking" (Say [1814] 2006, pp. 252-253).

This presentation of the imbalance between supply and demand has traditionally been interpreted as a statement of the so-called Say's Law (Keynes 1936, p. 18; Lange 1942, p. 154). Following this line of argument, for Say, the value of aggregate supply was equal to the value of aggregate demand. Therefore, a potential excess demand for a given commodity meant an excess supply of another commodity. Say conceded that "times when certain goods do not sell well, are precisely those where the prices of other goods become excessive" (Say [1814] 2006, p. 253). In fact, by declaring above that "many people bought less because they earned less," Say hinted at the possibility of negative carry-over effects (Jonsson 1997, p. 208). If supply was less than effective demand, too little of the means of production was used in a particular industry. As a result, the demand for other commodities was reduced. Economic crises, usually ascribed to oversupply, were in fact attributed, in Say's thinking, to underproduction (Allix 1910, p. 311). ${ }^{13}$

\footnotetext{
${ }^{13}$ Say added that imbalances between supply and demand would easily disappear in a sector totally devoid of barriers to entry. However, multiple obstacles could hinder the mobility of factors of production and prevent proper adjustment (Say [1814] 2006, p. 1104n1).
} 
The main insight of the second edition of Traité was Say's revised understanding that an increase in the demand for money would cause the quantity of money substitutes to increase. The other important insight was Say's revised interpretation of the relationship between excess supplies of some goods and excess demands for others. Say recognized that the failure to produce (or the failure of factor owners to sell their services) must have repercussions on the demand for output, because the demand for product was financed out of earned income.

\section{Onward: Product and Coordination Failures}

In the second edition of Traité, Say ([1814] 2006, p. 250) claimed "that a product is no sooner created than it opens, from that instant, an outlet for other products to the full extent of its own value." However, so long as the notion of product was undefined, Say's formulation remained unclear. It is no wonder that, facing the criticisms of Jean Charles Léonard de Sismondi (1819) and Thomas Robert Malthus (1820), Say became more specific. In his Lettres à M. Malthus, Say explained that the production of valuable products generated a corresponding flow of income, enabling those earning the income to demand whatever else had been produced (Say 1820, pp. 35-37). Say was careful to point out that the amount of income generated was equal to the value of the output sold, not to the value of the resources used to produce that output, so that the potential demand for output was limited by the value of what had been produced and sold; producing products that could not be sold for at least as much as their cost of production implied that resources had been wasted insofar as the resulting product did not generate sufficient income to absorb all the output that had been produced. ${ }^{14}$ Say reiterated the same idea in the epitome of Traité (Say [1826] 2006, p. 1105) and in Cours (Say [1828-29] 2010, p. 356). Say drew upon this refined definition of a product to analyze the demand function. Aside from a possible saturation of needs, what the buyer lacked, he indicated, was never the willingness to acquire something, but the means to do it. That is, the buyer lacked money (Say [1828-29] 2010, pp. 349-350). Say summarized his argument in the following terms: "[A] buyer is effectively ready to buy as long as he has money to do so ... he can only obtain money with the products he created, or those created for him; hence the fact that it is production that generates outlets" (Say [1826] 2006, p. 1105).

Say defined a sequential model whose guiding principle required that one needed to sell first in order to buy unless the exchange involved a credit purchase. Say's reasoning can be interpreted in two ways. In the first scenario, Say's proposition-a buyer was effectively ready to buy as long as that buyer had money to do so-was valid under the following condition: the total value of expected purchases in time period $t$ could not exceed the quantity of cash $\bar{M}_{t}$, the quantity of monetary substitutes $\bar{M}_{t}^{\prime}$, and the amount of potential credit from suppliers $-B_{t}$ :

$$
p_{t} q_{t} \leq \bar{M}_{t}+\bar{M}_{t}^{\prime}-B_{t}
$$

\footnotetext{
${ }^{14}$ Say wrote that "a product that does not reimburse its production costs, that is, a product whose monetary value does not cover profits and wages indispensable to satisfy [all] the needs ... of consumers, is not a product, it is the inert result of a useless effort, at least so long as its monetary value remains below its production costs" (Say 1824, p. 28n1).
} 
Since the buyer's holdings of money could come only from sales, the above-mentioned relationship validates Say's proposition according to which a product - in Say's sense of the word-opened an outlet for other products to the full extent of its own value. But another scenario was possible. First, individuals supplied services under the form of capital, labor, and land. Producers determined their production plan and demanded the required services in order to carry out their plan. Then, individuals used the proceeds received from producers who hired their services to demand products. If we follow this scenario to represent the agents' decisions (Appendix 1), we have the following results:

1. The demand of agents who were not able to sell their services is ineffective. This was exactly what Say meant when he declared that "many people bought less because they earned less" ([1814] 2006, p. 253). In Lettres à M. Malthus, Say (1820, pp. 100-101n1) applied a similar reasoning when he analyzed the fact that a worker's labor services could not be hired because his subsistence wage was too high.

2. The demand for commodities on the part of households depends on the product (in Say's sense). In our presentation, the demand for commodities depends on the value of factor services sold: that is, on the value of the output created. Investment from businesses depends on the difference between the value of the output based on market price and its value based on production cost.

3. By summing up the budget constraints when agents determine their demand for commodities, we obtain

$$
M^{d}-\bar{M}+B^{d}=p\left(\bar{q}-q^{d}\right)
$$

where $M^{d}$ denotes the desired level of money holdings, $\bar{M}$ the initial balance, $B^{d}$ the excess demand for assets (or excess supply of loanable funds), $p$ the vector of market prices, $\bar{q}$ the vector of quantities produced, and $q^{d}$ the vector of quantities demanded. From this, it appears that there can be a general oversupply whose counterpart is an excess demand for money or an excess demand for assets (excess supply of loanable funds).

All in all, for Say, the accumulation of capital generated higher output and thereby increased income, enabling increased consumption that eventually absorbed the surplus of income. Say concluded that every nation "is interested in the prosperity of all other nations because one can only sell to someone who is able to buy, and a nation ... can only buy with what it produced" (Say 1826a, p. 239).

The common thread between the various editions of Traité was that agents could somehow alter their holdings of money. In the first edition, Say noticed that holdings remained more or less unchanged during the course of a year; but he did not mean that it was always and necessarily the case. In the second edition, Say explained that agents could increase their holdings using monetary expedients to substitute for the lack of cash. Say later emphasized that the circular flow of output and income could be disrupted by dis-coordination between the suppliers of factor services and the demanders of factor services, thus causing changes in the holdings of money. Therefore, money demand was not constant. However, this conclusion emerged in a somewhat convoluted and fluctuating theory of production. 
Say's tergiversations on outlets were partly caused by the absence of a clear and coherent monetary framework, a shortcoming that would later be remedied in the fifth edition of Traité and especially in Cours. Over time, Say increasingly became aware of the limitations of his initial analysis on outlets. This led him to significantly revise his monetary views.

\section{SAY'S MONETARY THEORY}

Say's monetary thinking was based on the idea that the value of money was determined by supply and demand. ${ }^{15}$ This implied that money supply could differ from money demand. In other words, individuals could increase or decrease their holdings of money. Consequently, Say's monetary theory was logically incompatible with the so-called Say's identity. Enhancing the quantity of circulating medium could bring about prosperity.

\section{Money and Its Properties}

Say distinguished between two types of circulating medium: money stricto sensu (hereafter "money" as used by Say), and monetary substitutes (signes représentatifs). Money took the form of metal (gold and silver) and/or consisted of inconvertible paper money (papier-monnaie). Inconvertible paper money differed from banknotes, which could be converted into gold and silver. It was "a real money made of paper which does not stipulate its refund, or which stipulates a merely illusory refund which is not made" (Say [1826] 2006, p. 503). The circulation of inconvertible paper money was drawn upon the fact that the government authorized its use to pay debt and not on trust in the possibility of being converted into metallic money. It was thus "a true money, and not the representative sign of money" (Say [1826] 2006, p. 505). ${ }^{16}$ On the other hand, monetary substitutes-banknotes, bills of exchange, and promissory notes-were not considered to be money, but instead were instruments of credit. They were convertible monetary substitutes that had no value other than to give the bearer the right to receive a sum of money on par and on demand for banknotes, in function of asset maturity and uncertainty of payment for other substitutes (Say [1826] 2006, p. 517). ${ }^{17}$ While Say regularly maintained that the value of money was determined by supply and demand, he ([1814] 2006, p. 561) insisted on the fact that the actual value of substitutes such as bills of exchange and promissory notes was determined by the interest rate used to

\footnotetext{
${ }^{15}$ In Traité, Say wrote: "[W]e can see that money ... is a commodity whose value is set according to the rules applicable to all other commodities; that is, it rises depending upon the need one has, combined with its abundance" (Say [1803] 2006, p. 462). Say dittoed: "[M]oney, either in the form of specie or in bullions, is subjected to the law applicable to all other commodities: its exchangeable value, or relative price, depends upon the quantity of money in circulation, compared to the extent of the demand for it" (Say [1803] 2006, pp. 656, 658).

${ }^{16}$ It is worth noting that Say's definition of inconvertible paper money was exactly that of Huskisson (1810, p. 3), but differed from that of Ricardo, who indistinctively thought of convertible and inconvertible paper money as money.

${ }^{17}$ For Say, the circulating medium (agent de la circulation) included all types of monetary instruments: specie, inconvertible paper money, and monetary substitutes.
} 
discount them. It should be noted that, like the vast majority of French authors of the nineteenth century, he rarely discussed the relationship between the function of means of exchange and that of means of payment. Say was more explicit at times, though. For instance, he stressed that "the public puts its trust in the notes [issued by] a bank and accepts them as payment just like money" (Say [1826] 2006, p. 571). If it is so, this is because everyone is convinced that "one can painlessly convert them ... into cash anytime." Monetary substitutes were generally accepted as payment, but they could be refused, however. This is the reason why Say did not regard banknotes as money, though they conveniently substituted for it. Only metallic money and inconvertible paper money allowed final payment.

Say developed his monetary theory in connection with his theory of value. Like any other commodity, the value of money derived from its uses. The value of money was inversely related to its quantity. For instance, Say wrote in Cours: "[E]very time the number of monetary units has been increased, their value decreased proportionally, and ... it has increased as their number has been lowered" (Say [1828-29] 2010, p. 402). ${ }^{18}$ This inverse relationship between value and quantity was applicable to inconvertible paper money, as Say explained at great length in Traité and in Cours. For example, in reference to the Bank of England for the period from 1798 to 1818, during which convertibility was suspended, Say declared:

When bank executives, in collaboration with the government, intended to raise the value of the [inconvertible] banknotes to par with gold, they only had to reduce their quantity. The government partly refunded advances to the bank, which allowed a part of the notes to return; and the bank stopped discounting [new] bills while cashing the bills already in its portfolio whose maturity date expired daily; this even caused more bills to return. (Say [1826] 2006, p. 511)

When money took the form of metal, the situation was a bit more complex. The value of metal money was determined in an international market by supply and demand, with local monetary authorities being largely powerless to affect the value of money except by altering the standard or the conversion rate into the standard. In the short run, the stock of gold was fixed and the value of bullion was determined by the supply of the metal and the demand for the metal: "If the value of metal money is never less than the value of bullion of similar mass and purity, and if, for reasons we have discussed, it never rises above, we can conclude that the value of the metal rules, governs the value of money, and that the causes that determine the value of the metal thereby determine the value of specie made from it" (Say [1826] 2006, p. 469). ${ }^{19}$

If the market price of gold was greater than the production cost of mining, gold was produced, and that production added to the stock of gold. If the market price was less than the production cost, no gold was produced (Say [1826] 2006, p. 471).

\footnotetext{
${ }^{18}$ Say wrote likewise in Traité that "the value of money rises as money declines in quantity, and its value declines as it rises in quantity" (Say [1819] 2006, p. 289).

${ }^{19}$ In Cours, Say added that "the value [of bullion] is determined by the extent to which it can be used in the arts, or as export, that is, by the extent to which it is used as movable asset or as money worldwide" (Say [1828-29] 2010, pp. 402-403).
} 
Put differently, the price of gold was equal to the marginal cost of producing gold. However, if the value of gold on the domestic market was less than the value of gold on the international market, gold flowed out of the country, reducing the quantity of metallic currency according to the price-specie flow mechanism described by David Hume ([1752] 1826, p. 351) and adopted by Ricardo ([1810] 1951, pp. 56-57) and Say ([1819] 2006, p. 291n1).

For their part, monetary substitutes drew their value from the fact that they represented a guarantee of payment of a certain amount of money (Say [1826] 2006, p. 517). Therefore, as Say pointed out, the decreasing relationship between the value and the quantity of money implied a similar relationship between the value and the quantity of monetary substitutes (Say [1826] 2006, p. 473).

\section{The Quantity Theory}

Advocates of the quantity theory generally rely on two different formulations. One formulation of the theory rests on the existence of a market for money. Like any other commodity, the value of money is determined by the supply of and demand for money. Another formulation is based on the equation of exchange, which states that the total value of commodities traded during a given time period is equal to the product of the quantity of money by the velocity of circulation of money. Say entertained both versions of the quantity theory.

There is a plethora of references to the first formulation in Say's writings. Thus, Say ([1817] 2006, p. 462) intimated that "money is a commodity whose value is determined according to the common rules applicable to every commodity ... that is, [it is a] function of utility combined with its abundance." Say also relied on the equation of exchange, treating it not as an identity but as a condition of equilibrium: i.e., a causal relationship from money to prices. When the money stock rose, while the quantity of goods available remained unchanged, the quantity of money available for each good purchased also rose. As a result, in a stationary economy the value of money decreased in exact proportion to the rise in the quantity of money:

It is in the nature of things that, all else held constant in the circumstances of a country,
the value of money declines as the quantity of money in circulation increases. Indeed,
assuming the quantity of money currently circulating in France is two billion francs,
if for any reason, this amount in francs was suddenly raised to four billion, the quan-
tity ... of goods to be traded remaining the same, it is evident that no additional goods
would be offered for sale yet for each good on sale, twice as much francs would be
offered than what is currently offered; the four billion would not be worth more than
the two billion in current value; each franc would be worth fifty cents. (Say [1826]
2006, p. 457)

Say offered pristine reflections on the velocity of circulation often referred to as activité de la circulation in his writings, a concept that he applied to monetary instruments and commodities. For instance, in a long footnote in Cours, Say advanced that the demand for money within a country was a function of its wealth and the velocity of circulation. When wealth grew, the number of transactions rose, and thus individuals needed more money. The velocity of circulation was higher in rich countries 
(Say [1828-29] 2010, p. 405n1). However, the demand for money could change without a corresponding change in wealth. ${ }^{20}$

In light of Say's quantity theoretic positions, the existence of two types of circulating medium - money on the one hand and monetary substitutes on the other-raised an important question: What were their respective effects on prices? According to Say, changes in the quantity of monetary substitutes generated roughly the same effects on prices as changes in the quantity of money. Because they replaced money, convertible substitutes issued "truly increase[d] the number of monetary units and depreciate[d] their value" (Say [1826] 2006, p. 587). In Cours, Say ([1828-29] 2010, p. 475) added: "[A]s a bank puts its notes into circulation, and as long as the public agrees to receive it on the same condition as metallic money, the number of monetary units increases, and this increase necessarily brings down its value." This situation was only temporary, however. The equilibrium between the country and other nations could be restored only by the exports of metallic money (Say [1803] 2006, p. 576), a reasoning also put forth by Ricardo ([1810] 1951, pp. 54-55). Specie eventually disappeared from monetary circulation and there was no permanent increase in the circulating medium or any permanent increase in prices. ${ }^{21}$ Interestingly enough, Say thought the outflow of metal had real (albeit modest) effects on economic activity. Money was not neutral. The outflow of metallic money was in fact used to pay for imported goods, which Say considered "real wealth." The national capital was thus increased by an amount less than that of the paper issued.

Irrespective of the existence of two types of circulating medium, another critical question comes into play: Was the quantity of banknotes related to the quantity of bank reserves? On this issue, Say declared that "a well-managed bank always keeps in its [vaults] a certain quantity of cash in reserve equal, for instance, to two thirds of its banknotes in circulation, and that allows it to honor the first demands of reimbursement it may be subjected to" (Say [1826] 2006, p. 573). However, Say did not suggest that the quantity of banknotes in circulation was proportionally related to the quantity of metallic deposits. In other words, banks could raise or lower the amount of banknotes to be issued, depending on the economic environment.

Say's endorsement of the quantity theory was far from strict. In Cours and in the fifth and sixth editions of Traité, Say detailed several monetary expansion scenarios that spurred prosperity.

\section{Prosperity-Inducing Monetary Expansion}

Say conceded that an additional quantity of money not only affected prices, but also changed the distribution of wealth and promoted increased expenditure and output. Money was not neutral, contrary to a common interpretation of Say's thinking

\footnotetext{
${ }^{20}$ Say wrote: "In rich countries the velocity of circulation of money and commodities, allows to use a smaller quantity of money. A given sum is used for ten trades where it would only be used for one in a poor country. The quantity of goods in circulation, while growing, has not produced a proportional increase in the demand for money. The circulation has in fact been larger, but the circulating medium moved faster" (Say [1803] 2006, p. 666).

${ }^{21}$ While, in the case of convertible substitutes, prices increased only temporarily, enhancing the quantity of inconvertible paper would lead to a permanent increase in prices, however.
} 
(Lange 1942, p. 165). ${ }^{22}$ First, it should be noted that Say's analysis of the determinants of money demand corroborated the view that individuals could alter their holdings of money. We then analyze how and under what conditions, in Say's framework, monetary expansion stimulated the economy.

We saw in section II that agents could increase or decrease their holdings of money. In Cours, Say bolstered his case by pointing out that money demand depended on immediate cash constraints and expectations of future needs. Agents did not instantly spend their money; hence the gap between inflow and outflow of cash. Say identified three motives behind the desire to hold money: transactions, and precautionary and financial motives. First, Say described an income-elastic demand for money for transaction purposes: "What quantity of money will I need? The more sales and purchases I will have to carry out, the more money I will need. The manufacturer who needs to sell and purchase for an amount of five thousand francs every year, will use, in the course of a year, much more money than the porter who only receives in wage and consumes a thousand francs in the same time period" (Say [1828-29] 2010, p. 400). Say then referred to a money demand to cope with unforeseen contingencies: "[T]here are some types of occupation and consumption that always require to keep ... a certain sum to deal with unforeseen expenses" (Say [1828-29] 2010, p. 401). On the third motive, Say wrote that "as one loses interest in holding money, I assume that no one holds more [money] than one expects to use" (Say [1828-29] 2010, p. 401), and added in a footnote that "the money used ... to cover expenses inherent to the movement of business, is part of the capital of the firm; and the portion of money that remains idle ... is unproductive capital" (Say [1828-29] 2010, p. 401n1). Say did not write that the demand for money was a decreasing function of the interest rate, but such assertions logically imply that a higher interest rate lowered one's money holdings. ${ }^{23}$ Here, we have a conception of the interest rate defined as the reward for parting with cash. ${ }^{24}$ Say ([1828-29] 2010, p. 401) also justified the fact that hoarding was perfectly rational: "If some individuals hoard, we can consider that they strive to keep a treasure in reserve as a result of a need; and it can be argued that these individuals usually feel the need to keep with them a certain amount of [money] that better-advised individuals can employ to a better use."

Say's take on hoarding evolved over time. For instance, in the first edition of Traité, Say ([1803] 2006, p. 575n1) dismissed hoarding in conformity with his assumption of rapid disbursement of proceeds. In the fourth edition, Say ([1819] 2006, p. 247n1) considered hoarding insignificant in the very long run, though not over a shorter period.

\footnotetext{
${ }^{22}$ The expression "money is a veil," fallaciously attributed to Say, is nowhere to be found in his writings and is thus a myth as far as Say is concerned.

${ }^{23}$ There was no functional relationship between the interest rate and the demand for money in Say's writing - he did not use any mathematical formula; however, in our opinion the logic is inescapable. The decision to hold money, Say ([1828-29] 2010, pp. 149, 401) explained, was based on a choice between lending/investing and holding funds. Say brought to the fore the analytical mechanism that some economists (Allais 1947, pp. 238-241n11; Baumol 1952) would later use to develop the concept of demand for money.

${ }^{24}$ Say immediately clarified that "this proposition is not in contradiction with the one that instructs that money is not the same thing as capital," intimating that he did not recant his conception of the rate of interest as the price formed by the supply of and demand for loanable funds (Say [1828-29] 2010, p. 401n1).
} 
Thus, a miser could hoard money during his entire lifetime, Say pointed out, but it would eventually be spent by his heir. Say (1820, pp. 101-102n1) later blamed Ricardo for neglecting hoarding in the case of insufficient or ill-advised investment opportunities. In Cours, Say explained that sometimes individuals did not immediately spend their income: "Individuals who received their part of the products created in money form ... generally save it for a while in a form that is the most convenient, until the amount, which grows by several successive accumulations, is large enough to be invested. Thus, in every country there are many small portions of capital funds, whose employment is delayed and whose total amount ... form a very significant [part of] unproductive capital" (Say [1828-29] 2010, pp. 152-153).

In his discussion of unproductive capital, Say ([1828-29] 2010, p. 149) stated that "the lack of security and confidence often leads owners of capital funds to refrain from investing for fear of compromising them. They prefer to lose interest instead of risking the principal." Say explained that owners of idle capital funds factored risk and return in their decision making. The riskier and the less profitable the investment, the more capitalists would be incentivized to hoard. The take-away was that hoarding could involve large amounts, depending on the expected return and the level of risk. The fact of the matter is that, for Say, the interest rate not only affected the decision to hold bills of exchange and promissory notes, but also determined how long individuals held such assets. This clearly shows that Say described a form of money demand in which money was also a store of value, not just a medium of exchange.

According to Say, monetary expansion affected real variables throughout three channels. First, Say mentioned the wealth effects resulting from the issuance of paper money. In 1826, he underlined the effects of changes in the interest rate. Toward the end of his life, Say indicated that monetary factors could originate crises (section IV).

Like Hume and Smith, Say maintained that a country could profit from the issuance of banknotes. Banks would pocket the interest on the promissory notes they discounted in exchange for the banknotes issued. Individuals and merchants would also benefit from the issuance of banknotes, as it would accelerate the productive cycle and thus boost profit. Say pointed out that the issuance of banknotes would lead to higher prices; this would stimulate the economy, provided the price increase remained gradual and moderate (Say [1828-29] 2010, p. 479). Thus, Say recognized that the greater quantity of banknotes and inconvertible paper money, respectively, during the early stages of John Law's scheme and the early days of assignats, boosted the French economy. ${ }^{25}$ Say argued that since final prices grew faster than production costs, ${ }^{26}$ producers made significant profits that eventually allowed them to expand production. ${ }^{27}$ Say also noted

\footnotetext{
${ }^{25}$ Say used the same argument in the fifth and sixth editions of Traité (Say [1826] 2006, p. 505). Originally issued in 1790 as treasury bonds, assignats circulated as inconvertible paper money from 1791 to 1796.

${ }^{26}$ As example of production costs, Say mentioned leases and other rent charges that were generally fixed for several years.

${ }^{27}$ Interestingly, Say's analysis was very similar to Keynes's treatment of profit inflation in the Treatise on Money. Profit inflation occurred when prices were outrunning costs, leaving a large and growing margin for profit (Keynes [1930] 1971, 2, p. 137). Say referred to the exact same scenario. Furthermore, Keynes referred to gently rising prices_-just like Say, who alluded to a gradual and moderate price increase-and he took many historical examples from early-capitalist western Europe, which fit with Say's account. On Keynes on inflation, see Humphrey (1981).
} 
that inflation expectations could lead consumers to spend money more rapidly; in other words, inflation expectations could increase the velocity of circulation. Thus, total revenue would increase and thereby producers would recover their expenses more quickly.

Say then took up Tooke's arguments regarding the effects of an increase in the quantity of money on the interest rate. ${ }^{28}$ Additional money in the economy brought more lending, which resulted in a larger amount of capital funds that pushed the rate of interest down and subsequently lowered production costs. Prices then rose because of the abundance of money, but this effect occurred after the decline of the interest rate. Given that producers purchased their inputs before prices climbed, they profited from a low cost of borrowing. As they sold their products when prices went up, they ended up making large profits (Say [1828-29] 2010, p. 479). However, Say believed that the expansionary effects would sooner or later evaporate. He also underscored the harmful effects of inflation characterized by relative price imbalances and misallocation of resources. It is nonetheless true that, as he acknowledged, his monetary theory contradicted his initial framework in which commodities were purchased only with other commodities. Simply put, "in spite of the principles that teach us that money plays only the role of a simple intermediary, and that products can ultimately be purchased only with products, more abundant money fosters all sales and the reproduction of new values" (Say [1828-29] 2010, p. 479).

In Say's framework, increasing the quantity of circulating medium led to prosperity. Overall, what transpired from Say's thinking was the idea of a short-run endogeneity of circulating medium. ${ }^{29}$ As a result, money was not a mere token.

We now turn to Say's theories on economic crises. Here, too, Say acknowledged that monetary changes could affect expenditure and output.

\section{SAY ON ECONOMIC CRISES}

The conventional narrative about Say's explanation of economic downturns holds that overproduction and unemployment could temporarily occur in a particular industry, but equilibrating forces would allow swift adjustments; therefore, general overproduction or unemployment could not occur (Sowell 2006, p. 27). In reality, this interpretation of Say's crises theory is reductive and incomplete. Say admitted that economic crises could take place, but he rejected Malthus's and Sismondi's thesis, which held that crises resulted from too rapid capital accumulation. In Say's framework, crises could originate in two ways. As we saw in section II, he concluded that it was because

\footnotetext{
${ }^{28}$ Say ([1803] 2006, p. 764) initially posited that "when the quantity of money grows, its exchange value drops compared to that of other goods and does not affect the interest rate." Yet, toward the end of his life (Say [1828-29] 2010, p. 479), he adopted Tooke's views (Tooke 1826, pp. 22-24).

${ }^{29}$ Indeed, Say stressed that "in the first years of [John] Law's issuing bank, the French manufacturing sector was very active. The same effect was felt when assignats were first issued in $1791 \ldots$ In reality this effect would not be durable; because any decline in value must end or result in complete depreciation" (Say [1828-29] 2010, p. 479). However, Say recognized that the short-run effects could last quite a while: "[I]t is certainly true that the period of depreciation is somewhat stimulating and that this state can last for quite some time if the depreciation is very slow" (Say [1828-29] 2010, p. 479).
} 
the production of the missing products declined that the oversupplied products did not sell (Say [1814] 2006, p. 252). Crises resulted from an imbalance between supply and demand. Say (1826b) later developed a monetary theory of crises, which held that economic disturbances were caused by poor decisions on the part of banking institutions. This section analyzes whether Say's monetary theory of crises constituted a reinterpretation or a repudiation of his initial views on outlets.

\section{From Sector-Specific Disequilibrium to General Glut}

In the early nineteenth century, economists offered various interpretations of the imbalance between supply and demand. Ricardo ([1817] 1951, p. 263) intimated that "sudden changes in the channels of trade" created disequilibria that could be overcome by a transfer of capital from one employment to another. Sismondi $(1819,1$, p. 308) contended that such transfers were impossible because "workers employed by a producer who no longer obtain from buyers a price that allowed him to pay all advances, were rarely able to practice another occupation." Robert Torrens indicated that oversupply of a particular commodity led to a fall in its price that impeded producers from maintaining their initial level of production and purchases of inputs. As a result, this led to an oversupply of the goods used as inputs and thereby contributed to destabilize the economy. Thus, "a glut of a particular commodity may occasion a general stagnation and lead to a suspension of production, not merely of the commodity which first exists in excess, but of all the commodity brought to market" (Torrens 1821, p. 414). Additional causes of disequilibrium discussed were wars (Ricardo [1817] 1951, p. 265), poor crops (Say [1828-29] 2010, p. 350), government regulations (Say [1814] 2006, p. 253), and protectionism (Torrens 1819, p. 475). However, the main issue was to determine the extent of the market (Sismondi 1819, 1, p. 301). Say (1824, p. 27) acknowledged that gluts were caused by miscalculations on the part of entrepreneurs. Nonetheless, he remained optimistic and trusted their ability to turn things around (Say 1824, p. 28). In other words, Say explicitly considered the entrepreneur as the individual who oversaw the process of adjustment between supply and demand (Forget 1999, p. 174; 2003, p. 61).

In the first edition of Traité, Say ([1803] 2006, p. 688) claimed that "the total demand for products is always equal to the sum of products." The fact that one commodity could not sell was caused by the excess of means of production used to produce it and the consequent lack of means of production in another sector of the economy. Of what did the adjustment process consist? Say hesitated. In the same chapter, he came up with two conflicting scenarios. On the one hand, he wrote, that "the bad can only be temporary, because one soon stops making products that do not match the needs [of consumers] ... to focus on producing demanded goods" (Say [1803] 2006, p. 692). In other words, a simple transfer was required and Say seemed to consider that it was possible. On the other hand, he was doubtful, however: "[A]n inland county does not manage to sell its crops of wheat; but, if a manufacture is built, and if a portion of the funds and business used in agriculture were used in another type of production, the products of [both agriculture and the other type of production] will easily sell, although the quantity of products would have slightly increased" ([1803] 2006, p. 690). Here, too, Say invoked a transfer, but the process seems complex since it required the construction of a manufacture. In other words, one 
must invest in order for wheat to sell. One can even wonder whether it was necessary for the global product to grow in order to offset the surplus of wheat.

In the second edition of Traité, the previous passages disappeared. Say no longer mentioned inter-industry transferring of resources. As discussed in section II, Say stated that "a product is no sooner created than it opens, from that instant, an outlet for other products to the full extent of its own value" (Say [1814] 2006, p. 250). This quote has received much attention in the literature and remains one of the most controversial statements associated with the so-called Say's Law. But one should not be mistaken. Say did not use that formula to convey the idea that supply could not exceed demand. In reality, as Samuel Hollander (2005, p. 196) rightly points out, the initial imbalance between supply and demand pertained to a given sector of the economy, and did not reflect a global disequilibrium: surpluses and low prices in a given industry were counterbalanced by shortages and high prices elsewhere. Surpluses were not caused because the production of certain commodities was too high, but because the production of other commodities was not high enough (Say [1814] 2006, p. 253). Say later added that "if certain commodities do not sell, it is because other [commodities] are not produced; it is production alone that opens outlets to products" (Say 1820, p. 5). Say thus explained that English goods could not be exported to Brazil because Brazil did not produce enough goods: "[I]f Brazil produced enough to buy English products, they would not be oversupplied. It required Brazil to be more industrious, to have more capital" (Say [1819] 2006, pp. 253-254n3). Put simply, a net expansion of sectors in short supply by means of new investments would create new outlets for oversupplied industries.

\section{Money and Economic Crises}

In 1826, Say laid out a monetary theory of crises that led him to significantly revise his analysis on outlets. His text was originally written in response to Sismondi's article published in La Revue Encyclopédique in 1826. In that essay, Sismondi gave his account of the crisis that took place in England at the time. Surprisingly, he did not reiterate the thesis developed in a previous article titled "Sur la balance des consommations avec la production" that appeared in the same journal two years prior. In 1824, his idea was that crises could originate from an imbalance between supply and demand consecutive to technological change and thus create general gluts. Two years later, he no longer referred to that scenario. Sismondi (1826, p. 612) now focused on the organization of the banking system without suggesting that it was the root cause of the crisis, however. In fact, he reproached Ricardo and Say for believing that consumers would always be able to purchase what was produced, and for their incapacity to properly assess the state of the English economy (Sismondi 1826, p. 615). Say took the challenge and claimed that "far from invalidating the natural laws discovered by the leading authors, the latest [economic] crisis fully confirms them. It can be explained by Ricardo's principles on monies" (Say 1826b, p. 43). ${ }^{30}$

\footnotetext{
${ }^{30}$ The reference to Ricardo is misleading since he never formulated any monetary theory of crisis. In fact, Say referred to Ricardo's views on the relationship between the issuance of banknotes and the value of money.
} 
Say blamed both the behavior of agents and the organization of the banking system. In his mind, the 1825 crisis in England resulted from poor decisions on the part of banks; by discounting a disproportionate number of promissory notes issued by merchants, they spurred reckless speculation. It was thus possible for traders to engage in commercial activities without the required amount of capital. The abundance of monetary instruments in circulation led to a decline in the value of money compared with bullion. Holders of banknotes issued by the Bank of England rushed to commercial banks in order to redeem their notes into specie, and subsequently melted specie into bullion. The more the Bank of England supplied specie, the more it melted them to meet the growing demand for bullion. Constrained by the obligation of convertibility on the one hand and facing dried-out metallic reserves on the other, banks were consequently forced to interrupt their discounting operations. As a result, entrepreneurs could no longer issue promissory notes and thereby could not fulfill their commitments, leading to numerous bankruptcies.

Say restated the above-mentioned sequence in Cours ([1828-29] 2010, pp. 430, 487) and briefly in Traité ([1826] 2006, p. 586n1). He was somewhat hesitant when it came to specifying the starting point of the process, though. At first, Say argued that "an inconsiderate appeal for commercial enterprises led a significant number of speculators to expand their businesses beyond the reach of their capital stock" (Say [1828-29] 2010, p. 430). Thus, those entrepreneurs seemed to be the source of the downward spiral. Say rightly noticed that they would not have been able to play that role without the financial assistance of country banks who discounted promissory notes brought by speculators in exchange for banknotes. This scenario was similar to what John Stuart Mill ([1826] 1963-91) described around the same period. The difference was that Say incriminated entrepreneurs who engaged in risky operations whereas Mill ascribed the fault to investors who bid up the prices of commodities. But, further in Cours, Say underscored the fact that commercial banks discounted too many bills of exchange and, by that means, overissued banknotes. This second account was similar to the views developed by John Ramsay McCulloch (1826a, 1826b). The recession appeared to have originated from the banking sector. The overissue of banknotes caused some entrepreneurs to grow their business disproportionately, relative to their capital stock. In other words, they used an excessive amount of financial leverage. Say no longer referred to speculation from entrepreneurs. The increase in the quantity of banknotes generated inflation and depreciated the English currency. In response, banknote holders panicked and tried to redeem their assets in cash. Meanwhile, a significant amount of gold flowed out of the country, forcing the Bank of England to purchase gold at any price in order to keep up with the legal obligation of convertibility. ${ }^{31}$ Faced with mounting losses, the bank withdrew its banknotes from circulation and interrupted its discounting operations. Now, country banks constricted credit because they could not obtain banknotes from the Bank of England. As a result, merchants were deprived of the necessary resources to fund their business. They could not turn to banks to obtain finance and suppliers no longer accepted their bills. From that point on,

\footnotetext{
${ }^{31}$ Relying on Senior (1828, p. 29), Say noted that large amounts of gold flew out of England. One can assume that the outflow was consecutive to the rise in the relative price of English-made goods compared with foreign goods.
} 
the situation worsened. Merchants were compelled to sell their commodities at a loss. Prices dropped, unemployment rose, and bankruptcies escalated; hence, a general crisis: "Since all sorts of merchandise fell below their cost of production, a large number of workers remained unemployed; many bankruptcies hit traders and bankers, who issued banknotes without holding enough personal wealth, were left with nothing but the commitments of insolvent individuals as collaterals" (Say [1828-29] 2010, p. 488).

Say included this discussion in the chapter on outlets in Cours. He no longer mentioned that when money was scarce, it could easily be replaced by monetary substitutes. His reasoning suggested that it was not necessarily the case. Money may be lacking, but bills of exchange and banknotes were no longer accepted to settle transactions. The crisis propagated across the entire economy, workers were laid off, and businesses went bankrupt. This outcome is quite different from the overly reductive interpretation too often attributed to Say's analysis on outlets.

Say previously concluded that an increase in the quantity of circulating medium could stimulate the economy (section III). He then advanced, as indicated above, that such a development would lead to an outflow of gold and generate bankruptcies. In other words, according to Say, an artificial stimulus by means of an expansionary monetary policy sooner or later led to recession.

\section{CONCLUSION}

Our scrutiny of Say's views on outlets has brought to the fore a significant change in his thinking. Say firmly believed that the value of money was determined by supply and demand; therefore, he could not rest his law of outlets on the idea that individuals did not alter their holdings of money. Toward the end of his life-circa 1824-his change of views was equally noticeable. His statement according to which "a product is no sooner created than it opens, from that instant, an outlet for other products to the full extent of its own value" (Say [1814] 2006, p. 250) did not mean that supply created its own demand, but simply meant that the sale of goods increased one's holdings of money, which potentially, but not necessarily, allowed the purchase of other goods with the proceeds of the sale. In particular, Say came up with a sequential model in which failure to supply triggered a downward spiral of income and expenditure.

Say explicitly moved away from the implications of his law of outlets that conceived of money as a mere medium of exchange. Say eventually acknowledged that his monetary theory contradicted his initial articulations of the law. In fact, monetary changes not only affected prices, but also affected expenditure, output, and the distribution of wealth. His views on money, a major part of his work, should not be assessed through the narrow lens of Say's Law, but throughout his numerous writings on money, particularly in Cours and in the fifth and sixth editions of Traité.

How can we explain the evolution of Say's ideas on outlets and money? The economic situation of France changed after the Napoleonic Wars. The state of relative peace in Europe did not bring about economic stability. Instead, the frequency of economic crises intensified. The 1825 crisis sparked a large debate among classical economists. Say realized that monetary factors were at the heart of this crisis. Additionally, the discussions with Ricardo, Malthus, and Sismondi forced him to 
modify his initial framework. Without embracing the views of his correspondents, Say refined his arguments and abandoned some ideas he previously defended.

In the end, Say turned out to be much less dogmatic and categorical than often portrayed in the literature. In his own words, "overly absolute principles are exposed to the same drawbacks as a machine designed according to the laws of mechanics, but without taking into account frictions and the quality of materials" (Say [1826] 2006, p. 515).

\section{REFERENCES}

Allais, Maurice. 1947. Économie et Intérêt, présentation nouvelle des problèmes fondamentaux relatifs au rôle économique du taux d'intérêt et de leurs solutions. Paris: Imprimerie Nationale.

Allix, Edgar. 1910. "J.-B. Say et les origines de l'industrialisme." Revue d'Économie Politique 24 (4): 303-313; and (5): 341-363.

Baumol, William Jack. 1952. "The Transactions Demand for Cash: An Inventory Theoretic Approach." The Quarterly Journal of Economics 66 (4): 545-556.

—. 1977. "Say's (at Least) Eight Laws, or What Say and James Mill May Really Have Meant." Economica 44 (174): 145-161.

—. 1999. "Retrospectives: Say's Law." The Journal of Economic Perspectives 13 (1): 195-204.

Becker, Gary Stanley, and William Jack Baumol. 1952. "The Classical Monetary Theory: The Outcome of the Discussion.” Economica 19 (76): 355-376.

Béraud, Alain. 2014. "Jean-Baptiste Say et la question des débouchés." https://halshs.archives-ouvertes.fr/ file/index/docid/985506/filename/Say_et_les_dA_bouchA_s.pdf. Accessed 27 November 2017.

Blanc, Emmanuel, and André Tiran. 2003. "Introduction générale.” In Jean-Baptiste Say, CEuvres morales et politiques in Euvres Complètes de Jean-Baptiste Say. Paris: Economica.

Blaug, Mark. 1997. Economic Theory in Retrospect. Fifth edition. Cambridge: Cambridge University Press.

Clower, Robert, and Axel Leijonhufvud. 1973. "Say's Principle: What It Means and Doesn't Mean." Intermountain Economic Review 4 (2): 1-16. Reprinted in Axel Leijonhufvud, Information and Coordination. Essays in Macroeconomic Theory. Oxford: Oxford University Press, 1981, pp. 79-101.

Dupont de Nemours, Pierre-Samuel. 1770. "Note sur les Réflexions sur la formation et la distribution des richesses de Turgot.” Éphémérides du Citoyen 1: 123-134.

Eltis, Walter. 2005. "Money and General Gluts: The Analysis of Say, Malthus, and Ricardo." History of Political Economy 37 (4): 661-688.

Forbonnais, François Véron Duverger de. 1754. Éléments du Commerce. Second edition. Leyde, Paris: Bianson, David, Le Breton et Durand.

Forget, Evelyn. 1999. The Social Economics of Jean-Baptiste Say, Markets and Virtue. London and New York: Routledge.

- 2003. "Jean-Baptiste Say and the Law of Markets." In Steve Kates, ed., Two Hundred Years of Say's Law. Cheltenham: Edward Elgar, pp. 50-66.

Garnier, Germain. 1802. "Notes du traducteur." In Adam Smith, Recherches sur la Nature et les Causes de la Richesse des Nations. Volume 5. Paris: Agasse.

Hollander, Samuel. 2005. Jean-Baptiste Say and the Classical Canon in Economics. The British Connection in French Classicism. London and New York: Routledge.

Hume, David. 1752. "Of the Balance of Trade." In David Hume, Essays Moral, Political and Literary, Part II, Essay 5. London, Edinburgh. Reprinted in Philosophical works of David Hume. Volume III. Edinburgh: Adam Black and William Tait and Charles Tait, 1826.

Humphrey, Thomas MacGillivray. 1981. "Keynes on Inflation." FRB of Richmond Economic Review 67 (1): 3-13. 
Huskisson, William. 1810. The Question respecting the Depreciation of our Currency stated and examined. New edition, 1819. London: John Murray.

Hutcheson, Francis. 1725-26. "Reflections upon Laughter and Remarks on the Fable of the Bees." Dublin Weekly Journal, 11, 12, 13, 45, 46 and 47. Reprinted Glasgow: Daniel Baxter, 1750.

Hutt, William Harold. 1963. Keynesianism-Retrospect and Prospect: A Critical Restatement of Basic Economic Principles. Chicago: H. Regnery.

- 1974. A Rehabilitation of Say's Law. Athens: Ohio University Press.

Jacoud, Gilles, ed. 2013. Money and Banking in Jean-Baptiste Say's Economic Thought. London and New York: Routledge.

Jonsson, Petur. 1997. "On Gluts, Effective Demand and the True Meaning of the Say's Law." Eastern Economic Journal 23 (2): 203-218.

Kates, Steven. 1998. Say's Law and the Keynesian Revolution: How Macroeconomic Theory Lost Its Way. Northampton: Edward Elgar.

Kates, Steven, ed. 2003. Two Hundred Years of Say's Law. Northampton: Edward Elgar.

Keynes, John Maynard. 1930. A Treatise on Money. London: Macmillan. Reprinted in The Collected Writings of John Maynard Keynes. Volumes V and VI. London: Macmillan, Cambridge University Press, 1971.

- 1936. The General Theory of Employment, Interest and Money. London: Macmillan. Reprinted in The Collected Writings of John Maynard Keynes. Volume VII. London: Macmillan, Cambridge University Press, 1973.

— 1939. "Preface to the French edition." In J. M. Keynes, The General Theory of Employment, Interest and Money. London: Macmillan. Reprinted in The Collected Writings of John Maynard Keynes. Volume VII. London: Macmillan, Cambridge University Press, [1936] 1973, pp. $x x x i-x x x v$.

Lalor, John Joseph, ed. [1881] 1884. Cyclopaedia of Political Science, Political Economy, and of the Political History of the United States. New York: Charles Merill and Co.

Lambert, Paul. 1952. "La loi des débouchés avant J.-B. Say et la polémique Say-Malthus." Revue d'économie politique 62 (1): 5-26.

Lange, Oscar. 1942. "Say's Law: A Restatement and Criticism.” In Oscar Lange, Francis McIntyre, and Theodore Otte Yntema, eds., Studies in Mathematical Economics and Econometrics. In Memory of Henry Schultz. Chicago: University of Chicago Press, pp. 49-68. Reprinted in Oscar Lange, Papers in Economics and Sociology. Oxford: Pergamon Press, 1970, pp. 149-170.

Le Mercier de la Rivière, Pierre-Paul. 1767. L'ordre naturel et essentiel des sociétés politiques. Londres: Jean Nourse, Paris: Desaint.

Leijonhufvud, Axel. 1981. Information and Coordination. Essays in Macroeconomic Theory. Oxford: Oxford University Press.

Malthus, Thomas Robert. 1820. Principles of political economy considered with a view to their practical application. London: J. Murray.

McCulloch, John Ramsay. 1826a. "Thoughts on Banking.” Edinburgh Review 43 (86): 263-298. - 1826b. "The Late Crisis in the Money Market Impartially Considered." Edinburgh Review 44 (87): 70-93.

Mill, James. 1808. Commerce Defended. An Answer to the Arguments by which Mr. Spence, Mr. Cobbett and Others Have Attempted to Prove that Commerce is not a Source of National Wealth. London: Baldwin.

Mill, John Stuart. 1826. Paper Currency and Commercial Distress. Parliamentary Review. Session of 1826. London: Longman, Rees, Orme, Brown and Green, pp. 630-662. Reprinted in John Stuart Mill, Collected Works of John Stuart Mill. Edited by M. Robson. Volume IV. Toronto: University of Toronto Press, 1963-91, pp. 71-123.

- 1844. Essays on Some Unsettled Questions of Political Economy. London: John W. Parker.

Niehans, Jürg. 1990. History of Economic Theory: Classic Contributions, 1720-1980. Baltimore: Johns Hopkins University Press. 
Patinkin, Don. 1965. Money, Interest, and Prices: An Integration of Monetary and Value Theory. Second edition. New York: Harper \& Row.

Potier, Jean-Pierre. 2006. "Les traductions du Traité d'économie politique.” In J.-B. Say, Traité d'économie politique. Édition variorum in Euvres Complètes de Jean-Baptiste Say. Paris: Economica, pp. liii-1xxxi.

Ricardo, David. 1810. The high price of bullion, a proof of the depreciation of bank notes. London: John Murray. In The Works and correspondence of David Ricardo. Volume III. Cambridge: Cambridge University Press, 1951-1973.

—. [1817, 1819] 1821. Principles of Political Economy and Taxation. London: John Murray. Reprinted in The Works and Correspondence of David Ricardo. Volume I. Cambridge: Cambridge University Press, 1951-1973.

Say, Jean-Baptiste. [1803, 1814, 1817, 1819, 1826, 1841] 2006. Traité d'économie politique ou simple exposition de la manière dont se forment, se distribuent et se consomment les richesses. Édition variorum in Cuvres Complètes de Jean-Baptiste Say. Paris: Economica.

- 1820. Lettres à M. Malthus. Londres, Paris: Bossange.

. 1824. "Balance des productions avec les consommations." Revue Encyclopédique 23 (67): $18-31$.

1826a. "Économie politique." In Encyclopédie Progressive. Paris, pp. 217-304.

- 1826b. "De la crise commerciale de l'Angleterre." Revue Encyclopédique 32 (10): 40-45.

- [1828-29, 1840] 2010. Cours complet d'économie politique pratique. Édition variorum in Euvres complètes de Jean-Baptiste Say. Paris: Economica.

Schoorl, Evert. 2013. Jean-Baptiste Say: Revolutionary, Entrepreneur, Economist. Abingdon and New York: Routledge.

Senior, Nassau William. 1828. Three Lectures on the Transmission of the Precious Metals from Country to Country. London: John Murray.

Sismondi, Jean Charles Leonard de. 1819. Nouveaux Principes de l'Économie politique ou de la Richesse dans ses Rapports avec la Population. Paris: Delaunay, Treuttel et Wurtz.

. 1824. "Sur la balance des productions avec les consommations." Revue Encyclopédique 22: 264-298.

— 1826. "Nouveaux principes d'économie politique, jour qu'ils peuvent jeter sur la crise qu'éprouve aujourd'hui l'Angleterre.” Revue Encyclopédique 31: 608-618.

Skinner, Andrew Stewart. 1967. "Say’s Law: Origins and Content." Economica 34 (134): 153-166.

Smith, Adam. 1776. An Inquiry into the Nature and the Causes of the Wealth of Nations. London: Strahan and Cadell. Reprinted in the Glasgow edition of the Works and Correspondence of Adam Smith. Oxford: Oxford University Press, 1976.

Sowell, Thomas. 1972. Say's Law: An Historical Analysis. Princeton: Princeton University Press.

_ 1987. "Say's Law.” In John Eatwell, Murray Milgate, and Peter Newman, eds., The New Palgrave: A Dictionary of Economics. Volume 4. London: Macmillan, pp. 249-251.

- 2006. On Classical Economics. New Haven and London: Yale University Press.

Steiner, Philippe. 2006. "Les Traités d'économie politique, préface à Say.” In J.-B. Say, Traité d'économie politique. Paris: Economica, pp. ix-lii.

Steuart, James. 1767. An Inquiry into the Principle of Political Economy. London: A. Millar and T. Cadell. Reprinted London: Pickering and Chatto, 1998.

Thweatt, William Oliver. 1979. "Early Formulators of Say's Law." Quarterly Review of Economics and Business 19 (Winter): 79-94. Reprinted in John Cunningham Wood and Steve Kates, eds., Jean-Baptiste Say: Critical Assessments of Leading Economists. Volume 5. London and New York: Routledge, 2000, pp. 78-93.

Tiran, André. 2003. "Théorie du système monétaire chez Jean-Baptiste Say.” In Jean-Pierre Potier and André Tiran, eds., Jean-Baptiste Say. Nouveaux regards sur son æuvre. Paris: Economica, pp. $403-428$.

Tooke, Thomas. 1826. Considerations on the State of the Currency. London: John Murray. 
Torrens, Robert 1819. "Mr. Owen's Plans for Relieving the National Distress." The Edinburgh Review or Critical Journal 32 (54): 453-477.

-1821. An Essay on the Production of Wealth. London: Longman, Hurst, Rees, Orme and Brown.

Turgot, Anne Robert Jacques. [1766] 1769, 1770. "Réflexions sur la formation et la distribution des richesses." Éphémérides du Citoyen ou Chroniques de l'esprit national 1769, 11: 12-56, and 12: 31-97; 1770, 1: 113-172. Reprinted in Euvres de Turgot et documents le concernant. Edited by Gustave Schelle. Volume 2. Paris: Alcan, 1914, pp. 533-601.

Whatmore, Richard. 2000. Republicanism and the French Revolution: An Intellectual History of JeanBaptiste Say's Political Economy. Oxford, New York: Oxford University Press.

Wood, John Cunningham, and Kates Steven, eds. 2000. Jean-Baptiste Say: Critical Assessments of Leading Economists. London and New York: Routledge.

\section{APPENDIX 1: THE BUDGET CONSTRAINTS}

In his reinterpretation of Say's law, Oscar Lange ([1942] 1970) relied on a Walrasian-type model in order to derive the budget constraints. His model hypothesizes that all markets are simultaneous, that agents have knowledge of all prices when they determine their decisions of consumption and production, and that agents know that trades will take place only at equilibrium prices. In other words, it is assumed that agents are certain to be in capacity to execute all planned trades. In such a scenario, the total value of demand is equal to the total value of supply. A potential excess supply of a given commodity necessarily involves an excess demand for other commodities.

However, Say described a sequential model whose guiding principle required that one needed to sell first in order to subsequently buy. Transactions are not simultaneous but consecutive, so that disequilibrium in one market affects other markets. If, at times, some products do not sell, it is because "many people bought less because they earned less" (Say [1814] 2006, p. 253). In such a scenario agents' planned trades are not necessarily realized.

To illustrate the difference between a Walrasian-type model and a sequential model, we consider a simplified formalization consisting of a closed economy with two types of agents - firms and consumers-and four types of commodities: factor services, products, financial assets, and money. Financial assets (loanable funds) are traded from one agent to another in exchange for interest paid on Sunday night. These assets are not subject to trades on a secondary market. The quantity of money is given. The markets for factor services take place on Monday, say in time period $t$. The markets for products take place on Saturday, say in time period $t+1$. We postulate that the markets for loanable funds open on Monday and Saturday.

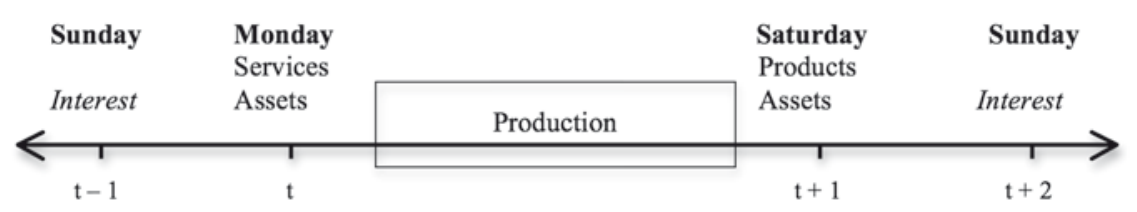

Now consider an individual $h$ who first sells and buys factor services under the form of labor, capital, and land. $\bar{M}_{t-1}^{h}$ denotes the initial money holdings at his disposal, $\bar{B}_{t-1}^{h}$ denotes the initial quantity of assets or liabilities (-), and $\bar{q}_{t-1}^{h}$ denotes the vector of initial quantities of products (inventory). For a given vector of prices of services, $w_{t}$, and a given vector 
of expected prices of products on Monday for Saturday, $p_{t}^{e, h}$, the individual $h$ determines, $l_{t}^{s, h}$, the vector of quantities of services supplied (+) or demanded (-). Simultaneously, the individual $h$ determines the quantity of products, $q_{t}^{e, h}$, the quantity of money, $M_{t}^{e, h}$, and the total value of assets, $B_{t}^{e, h}$ that he plans to hold after the market for products closes on Saturday. The budget constraint is

$$
B_{t}^{e, h}+M_{t}^{e, h}+p_{t}^{e, h} q_{t}^{e, h}=w_{t} l_{t}^{s, h}+\bar{M}_{t-1}^{h}+\bar{B}_{t-1}^{h}+p_{t}^{e, h} \bar{q}_{t-1}^{h}
$$

The firm $f$ is endowed with the quantity of money $\bar{M}_{t-1}^{f}$, some assets of value $\bar{B}_{t-1}^{f}$, and some products $\bar{q}_{t-1}^{f}$. Considering the expected product prices, $p_{t}^{e, f}$, the firm determines, for a given vector of prices of services, $w_{t}$, the quantity of products that it plans to produce, $q_{t}^{e, f}$, the quantity of services, $l_{t}^{d, f}$, the quantity of money, $M_{t}^{d, f}$, and the assets, $B_{t}^{d, f}$. The firm's budget constraint can be written as such:

$$
B_{t}^{d, f}+M_{t}^{d, f}+w_{t} l_{t}^{d, f}=p_{t}^{e, f} q_{t}^{e, f}+\bar{M}_{t-1}^{f}+\bar{B}_{t-1}^{f}+p_{t}^{e, f} \bar{q}_{t-1}^{f}
$$

For this vector of prices of services $w_{t}$, the markets for services are not necessarily in equilibrium (in accordance with Say's reasoning); therefore, the total quantities traded are not necessarily equal to the quantities supplied or demanded. Let $\bar{l}_{t}^{h}$ be the vector of quantities of services sold by individual $h$. On Monday night, his money holdings, $\bar{M}_{t}^{h}$, and the total value of his assets, $\bar{B}_{t}^{h}$, are determined by the following equation:

$$
\bar{B}_{t}^{h}+\bar{M}_{t}^{h}=w_{t} \bar{l}_{t}^{h}+\bar{M}_{t-1}^{h}+\bar{B}_{t-1}^{h}
$$

The money holdings $\bar{M}_{t}^{f}$ and assets $\bar{B}_{t}^{f}$ of firm $f$ are determined by the following relationship:

$$
\bar{B}_{t}^{f}+\bar{M}_{t}^{f}+w_{t} \bar{l}_{t}^{f}=\bar{M}_{t-1}^{f}+\bar{B}_{t-1}^{f}
$$

considering that $\sum_{h} \bar{l}_{t}^{h}=\sum_{f} \bar{l}_{t}^{f}$. On Saturday, the individual $h$ uses the resources at his disposal to demand products:

$$
M_{t+1}^{d, h}+B_{t+1}^{d, h}+p_{t+1} q_{t+1}^{d, h}=\bar{M}_{t}^{h}+\bar{B}_{t}^{h}+p_{t+1} \bar{q}_{t-1}^{h}
$$

During the week, the firm $f$ produces a quantity of products $q_{t}^{f}$. The firm's market supply is the quantity of products $\bar{q}_{t-1}^{f}+q_{t}^{f}-q_{t+1}^{d, f}$ :

$$
M_{t+1}^{d, f}+B_{t+1}^{d, f}+p_{t+1} q_{t+1}^{d, f}=\bar{M}_{t}^{f}+\bar{B}_{t}^{f}+p_{t+1}\left(\bar{q}_{t-1}^{f}+q_{t}^{f}\right)
$$

It is assumed that profits or pure losses - the difference between total revenue and total cost, $p_{t-1} \bar{q}_{t}^{f}-w_{t} \bar{l}_{t}^{f}$-are not distributed to shareholders, but they are used by the firm to fund its investment, reduce its liabilities, or simply increase its money holdings.

By adding up the two previous expressions and assuming that someone's assets are someone else's liabilities $\left(\sum_{h} \bar{B}_{t}^{h}+\sum_{f} \bar{B}_{t}^{f}=\bar{B}=0\right)$, we draw the following expression of Say's Law of outlets: 


$$
M_{t+1}^{d}+B_{t+1}^{d}+p_{t+1} q_{t+1}^{d}=p_{t+1}\left(\bar{q}_{t-1}+q_{t}\right)+\bar{M}
$$

If supply is all sold, then the right-hand side (notional supply) shows the amount of purchasing power firms would have, plus the existing money balances held over from the last period. The left-hand side (notional demand) shows what that purchasing power might be used for: to purchase products, additional assets, or additional money. If the notional demand for products is not equal to the notional supply, we have $p_{t+1}\left(\bar{q}_{t-1}+q_{t}-q_{t+1}^{d}\right)>0$, which means $M_{t+1}^{d}-\bar{M}+B_{t+1}^{d}>0$ : agents tend to increase their money holdings or reduce their liabilities. This relationship differs from Walras's law in that an imbalance in the market for factor services is possible while other markets are in equilibrium. If an individual $h$ does not sell the services he supplies, he will not be able to demand the products that he planned to purchase. Moreover, if the vector of quantities of products demanded does not equal the vector of quantities supplied, some products will not be sold, and hence owners of those products will be left with inventories of unsold items rather than income, and so unable to buy what they would have bought. Demand depends on successful sales. 